\title{
DOI 10.26886/2414-634X.4(23)2018.15
}

UDC: $241.8: 261.6$

\section{STANLEY J. GRENZ'S THEOLOGICAL METHOD: A POSTFOUNDATIONAL EPISTEMOLOGY}

\section{Yevgen Shatalov}

National Pedagogical Dragomanov University, Ukraine, Kyiv

In the present article, I have examined the communitarian theological method of Stanley J. Grenz. The article was dedicated to outlining Grenz's overall proposal for reshaping evangelical theology along communitarian lines due to a major cultural shift from modernity to postmodernity. To his mind, evangelical scholars can benefit the most in their theologizing from this communitarian methodological orientation. Drawing on the works of other postfoundational scholars and my personal research in the Eastern European context, I have suggested revising certain aspects of Grenz method (in particular the structure of epistemology, the question of language and truth). Taking my conclusions as a starting point, I tried to put Grenz's communitarian methodology into practice in order to present the contours of revisited communitarian method. I have demonstrated that contemporary evangelical theology, indeed, requires the notion of community due to biblical, theological, sociological, hermeneutical and apologetic reasons. While Grenz did not dedicate much writing to such questions as relationship between theology and Tradition (an exception is his work on the role of Tradition in postfoundational epistemology, unto which I drew), I have expanded them following his overall emphases. Therefore, I have concluded that Grenz's communitarian methodology can be applied well to theology if certain aspects could be revised.

Key words: Stanley J. Grenz, theological method, evangelical theology, postfoundational epistemology, concept of community. 
Approaching the practice of theology entails developing a certain methodology that will guide one's research. As the shift from modernity to postmodernity became apparent in various areas of our society, many evangelical scholars realized the need for revisiting traditional theological methods they used. The quest for a theological method brought diverse proposals, from conservative to more radical, for doing evangelical theology. Stanley J. Grenz is one of those thinkers who tried to utilize various insights of a postmodern ethos in order to present his comprehensive approach to theology. Being sensitive to contemporary cultural and philosophical milieu, but, at the same time, faithful to historical Christian faith and practice, Grenz came up with a methodology in which the concept of community became the locus of theological enterprise.

This article is dedicated to Grenz's theological method. If above we have outlined a large picture of Grenz's theological enterprise, below we will see the way of painting it. In Grenz's view, one of the postmodernism's most helpful aspects for the doing of theology is the epistemological shift from foundationalism to a "chastened rationality." This entails first, the rejection of the Enlightenment project to ground knowledge in basic beliefs that are universal, objective, indubitable, and discernable to any rational person; and second, the acceptance of "the transition from a realist to a constructivist view of truth and the world" [5, p.22]. To the closer examination of this shift we turn now.

\section{Language, Theological Knowledge and Reality}

Grenz, in his book coauthored with Franke, states: "language... provides the conceptual tools through which we construct the world we inhabit, as well as the vehicles through which we communicate and thereby share meaning with others. ... Theology, we might conclude, explores the world-constructing, knowledge-forming, identity-forming 'language' of the 
Christian community" [lbid., p.53]. Here we can see that language becomes a primary focus for Grenz's (and Franke's) project. Grenz's indebtedness to contemporary sociology of knowledge and linguistics is vivid in the following quotation: "we do not inhabit the 'world-in-itself'; instead, we live in a linguistic world of our own making" [5, p.53]. This phrase of Grenz (and John Franke) became the most quoted by many opponents of their program. Anyone acquainted with a constructivist epistemology knows that such statements presuppose perspectivalism and hence relativism as a result. According to the constructivist view language forms our knowledge and one's perspective always forms the grid out of which the world is interpreted and understood. Thomas Kuhn's paradigms, or an ordered set of methods and ideas shaped by a certain (scientific) community, might well stand for a perspective. Narrative thinkers describe perspectives as intellectual frameworks, which represent structure of one's beliefs. The image of spider webs, often used by Grenz, shows that our beliefs gain strength from the mutually reinforcing effect of all the internal connections and not from some kind of foundation. Elsewhere, Grenz even states that our knowledge is but perspectival. Nevertheless, while accepting the social construction model of knowledge, he still, together with realists, believes that there is certain "givenness to the universe" apart from our linguistic tasks. This "givenness" is not the "world as it is", but rather the world, as seen "through the lenses of the gospel, the objectivity in the biblical narrative is the objectivity of the world as God wills it" [5, p.246]. So, Grenz views objectivity through an eschatological prism and defines it as "the world as God wills it to be," as objectivity of a future and eschatological world [5, p.53; 2, p.223-24]. And the language neither "penetrates" nor "reveals" this reality, but rather "creates" it. By means of connecting this "givenness" to the will of God, Grenz equates objectivity with eschatological future, with "eschatological realism" that shapes a social constructivist 
understanding of the shared human task. Further, since truth in its fullness can be known only in the future, when eschaton comes to its realization, all our present theological statements are provisional and should be treated as hypotheses to be tested. (Therefore we cannot really talk about any knowledge as truly objective). The eschatological completion of God's creative activity becomes a vantage point through which the universe should be viewed $[9$, p.176]. At this point Grenz recognizes his indebtedness to Wolfhart Pannenberg with his appeal to the eschatological nature of truth and to George Lindeck's "cultural-linguistic" approach to reality which moves from realism to the concept of social construction of reality. (Also Grenz reveals his indebtedness to the sociology of Peter Berger and Thomas Luckmann). Grenz differs with Lindbeck in that he moves beyond Lindbeck's thesis and states that theology cannot be purely descriptive but also prescriptive, i.e. work as the "interpretive framework of the Christian community" [5, p.197-199].

Grenz believes that truly communitarian theology should employ a nonfoundationalist epistemology that combines such approaches as coherentism, pragmatism and the Wittgenstein's notion of language-games. At this point the notions of language and reality meet each other. According to Grenz coherentism rejects the assumption that a justified set of beliefs necessarily comes in as an edifice which rests on a base. For him there are no beliefs that are intrinsically basic or superstructure. Coherentism views beliefs as a mosaic or web, where each belief is interdependent and supported by its relationship to other beliefs within mosaic, and justified by its overall fit with other held beliefs. Pragmatism, like coherentism, sees the truth not in beliefs corresponding to reality but is tested and experimentally confirmed [9, p.169]. The truth for Grenz should also be proved pragmatically. While, as he said, other religions might participate in the divine plan of building community, only Christianity carries within itself the 
foundation for the community-building role of a transcendent religious vision [5, p.281-83]. Therefore, Christian view of truth for Grenz is more coherent and more pragmatic then the truth of other religions.

Reconstructing the Foundation - Community as the Postfoundational Epistemological Foundation

If, as contemporary critics of Enlightenment epistemology say, there is no single, universal set of criteria for judging definitively the epistemic status of all beliefs, and if there is no such thing as neutral reason, in which truly objective reflection take place, can we talk about foundations in our epistemology? To find an answer to this question Grenz consults with some Reformed epistemologists and concludes that theological reflection has a believing community as its "foundation." $\mathrm{He}$ believes that a nonfoundationlist communitarian approach "returns theological reflection to its proper primary location within the believing community, in contrast to the Enlightenment ideal that effectively took theology out of the church" and actually views Christian theology "as an activity of the community that gathers around Jesus the Christ" [lbid., p.47-48].

All Christians share an experience of being encountered redemptively in Jesus Christ by the God of the Bible. By means of this encounter God constitutes us individually as believers and corporately as a community of faith. As a result, this encounter with God is an identity-producing event. Therefore, Grenz sees Christians as storytellers, who "recite narratives that recount their historical and ongoing personal encounter with God" in the categories drawn from the biblical narrative. Being aware of liberal pitfalls on the path of Christian experience Grenz does not equate the encounter with God to a mere universal mark of believers. On the contrary, he believes that any experience is always mediated by certain community and thus always conditioned by it (and its traditions). In conclusion we may say that specifically "Christian-experience-facilitation interpretative framework, 
arising as it does out of the biblical narrative, is 'basic' for Christian theology" and epistemology [Ibid., p.49]. In this Grenz partly fulfills Lindbeck's program of "intratextual theology" that in his words should "redescribe reality within the scriptural framework" in order to incorporate "all being into a Christ-centered world" [7, p.118]. As I have noted earlier Grenz shares Lindbeck's thesis and presents it in a rather new way for traditional evangelical theology. Elsewhere Stanley Grenz says that doctrines comprise something like rules of discourse of the believing community and thus act like norms which regulate and instruct adherents how to act and think. In short for Grenz "doctrines establish the ground rules for the 'game' of Christian thinking, speaking, and living" [5, p.46].

Church for Grenz is then more than an integrative motif of theology; it is an epistemological foundation as well. This is why Grenz calls church "basic" or "given" for our epistemological endeavor. We know that the process of knowing always takes place within the context of prior belief. In order to grow in knowledge a person needs to make a provisional commitment to a framework of thought, to accept something as "given" on trust and then to pursue it in examination. (At this point Grenz acknowledges church to be this "given" with which one proceeds in knowing God) [8, p.295]. Since belonging to community is a part of our human existence and it shapes our conceptions of rationality together with basic religious beliefs, every theology is necessarily communitarian [5, p.230-31]. In other words the existence of the church is "basic" in a sense that it objectively exists regardless of our beliefs and any theologian should attempt to explain why and how it does exist.

The church is indebted for its "basicality" to one's encounter with God of the Bible through Jesus Christ. It can truly be deemed "basic," because it is the only mean by which the Spirit constitutes us as a community. The church is also basic "in that our participation in the faith community calls 
forth theological reflection" and therefore our theological construction needs no certainty-gaining foundations but "the life of the discipleship community who are joined together by the Spirit and who join together in living out the mandate they share" [1]. Theology then is the ongoing conversation among the members of community to clarify the interpretive framework of the community that this encounter has called forth. Thus Grenz states that it is "the specifically Christian-experience-facilitating interpretative framework" that is also "basic" for theology and the church itself. However, because this experience and its interpretative framework cannot exist without the church we can say that church is indeed "basic" for theology [5, p.233-34]. This communitarian nature of theological foundation then shows that Christian theology should be communitarian.

Relationships between Theology and Tradition

Grenz elevates Scripture to be the primary norm for theological statements and reflections, but, as he puts it, "contextualization demands that we take seriously the thought-forms and mindset of the culture" in which we articulate our theology [5, p.19]. He encourages those who want to communicate the gospel in the contemporary world to be aware that the theological categories we employ are always culturally and historically conditioned. Hence, the cultural mindset and context should be considered in the theological enterprise. As a result, Grenz presents his "three sources or norms for theology" which are the Bible and its message per se, the theological heritage of the church, and "the thought-forms of the historicalcultural context in which the contemporary people of God seek to speak, live, and act" [lbid., p.112-115].

Grenz acknowledges that even though Protestants confess sola scriptura and the principle, that there is no norm over Scripture, "scriptura is never sole." Note that for him it is due to the Spirit's work the Bible gain its authority. Since the same Spirit works in the Christian community biblical 
texts gain their distinctive shape only in the community. As Grenz states "apart from the Christian community the Christian Bible would not exist" [5, p.112]. So, speaking about the authority of Scripture Grenz places it not in the text itself but rather in the work of the Spirit who speaks in and through the text. Therefore, the authority of the Bible "is ultimately the authority of the Spirit whose instrumentality it is" [6, p.224]. Actually this link between the Word and the Spirit is fundamental to his theological method. Such pneumatological understanding of the biblical authority will lead us consequently to an appreciation of Christian Tradition, since Spirit reveals Himself there, as well. Grenz further states that the path to such understanding "proceeds indirectly, via ecclesiology" because "Scripture arose in the ancient faith communities" [lbid., p.224]. However Grenz notes that as the faith community affirmed the canon, it made itself accountable to Scripture as the norming norm for its life, faith and practice. Moving forward Grenz and Franke define Christian tradition as "the ongoing historical attempts by the Christian community to explicate and translate faithfully the first-order language, symbols and practices of the Christian faith - by means of the interaction among community, text and culture - into the various social and cultural contexts in which the community has been situated" [lbid., p.228]. This definition gives a dynamic hue to Tradition for it has to grow as it confronts new challenges and situations over the course of time [4, p.373]. The reading of Scripture, for Grenz, should always be in "hermeneutical fellowship with all the people of God" because we ourselves are not the only people of God but "the contemporary embodiment of a historical people, the people of God throughout the ages" [1].

Relationships between Theology and Culture

Every human is embedded in culture and cannot receive any message "outside" of his or her social context. Following contemporary cultural anthropologists Grenz rejects the older definition of culture that 
viewed it as a "thing" or entity standing above human products and as learned mental structures. Rather, he sees it as an "outcome and product of social interaction" where people are not its passive receivers but active creators who "struggle to determine the meaning of public symbols" [5, p.135]. Therefore, culture is simultaneously private, since meanings of shared cultural symbols are always subject to private interpretation, and public because there are still presupposed models of the world that are widely shared [lbid., p.137-38]. Grenz believes that the task of the person within any given social context is the construction of meaning. In other words, the meaning-making cultural endeavor is the formation of personal identity within the particular context of the social group. Henceforth the construction of the worlds we inhabit together with formation of our personal identity is an ongoing and dynamic process, in which shared cultural meanings are being formed and reformed. While symbols of every culture are mostly given we still struggling together to determine the meaning of those symbols we employ in this process.

Grenz states that in any communication culture becomes a crucial tool. Since doing theology is always communicating something about God it necessitates us to conceptualize and articulate Christian beliefs in a manner that contemporary people would understand. That is theology should be expressed through the symbols and "language" of the culture. In this, Grenz believes, lies our missiological calling. And henceforth theological enterprise should do well to draw from "cultural artifacts" because they present a window into the psyche of the society we live in [5, p.159]. Thus, theology should use culture. We should also realize the fact that our cultural context and any particular cultural expression in some way lead us to reconsider our understanding of the Christian faith. As Grenz puts it, "reading our culture can assist us in reading the biblical text to hear more clearly the voice of the Spirit" [lbid., p.160]. In his mind this is evident 
because Sprit always speaks to us through the Scripture within a specific historical-cultural context. This notion makes our conversation with cultural context of crucial importance to the hermeneutical task. Grenz believes that in the hermeneutical process discoveries and insights of the diverse disciplines of human knowledge should inform our theological construction. He sees an ally especially in contemporary anthropology that can help us to understand better how human identity is being formed, how sin affects us etc. Theology should draw from all human "secular" knowledge because in fact ultimately no discipline is purely secular and all truth ultimately comes together in God.

Speaking in general about Grenz's methodology, I can say that the great amount of criticism launched against him often misunderstands or misrepresents it. While Grenz utilizes much of postmodern thought and operates from postconservative perspective he, nevertheless, makes a lot of modifications, and thus, creatively presents his methodology. I, therefore, conclude that the concept of community is vital for theology, and it appears that Grenz's method suffers the most inadequacies in the epistemology.

\section{References:}

1. Grenz Stanley J. Conversing in Christian Style: Toward a Baptist Theological Method for the Postmodern Context in Baptist History and Heritage 35/1 (Winter 2000): 82-10, available at: http://www.encyclopedia.com/doc/1G1-94160872.html (25 March 2018).

2. Grenz Stanley J. The Moral Quest: Foundations of Christian Ethics. Downers Grove, Illinois : InterVarsity Press, 1997.

3. Grenz Stanley J. Theology for the Community of God. - Carlisle, U.K.: The Paternoster Press, 1994.

4. Stanley J. Grenz, The Spirit and the Word: The world-creating function of the text in Theology Today 57:3 (October 2000). 
5. Grenz Stanley J. and John R. Franke. Beyond Foundationalism: Shaping Theology in a Postmodern Context. - Louisville, Kentucky: Westminster John Knox Press, 2001.

6. Grenz Stanley J. and John R. Franke. Theological Heritage as Hermeneutical Trajectory: Toward a Nonfoundationalist Understanding of the Role of Tradition in Theology in Ancient \& Postmodern Christianity: Paleo-Orthodoxy in the 21st Century, eds. Kenneth Tanner and Christopher A. Hall. - Downers Grove, IL: InterVarsity Press, 2002.

7. Lindbeck George A. The Nature of Doctrine: Religion and Theology in a Postliberal Age. - Philadelphia, PA: Westminster Press, 1984.

8. Vanhoozer Kevin J. The Drama of Doctrine: A Canonical-Linguistic Approach to Christian Theology. - Louisville, KY: Westminster John Knox Press, 2005.

9. Wellum Stephen J. Postconservatism, Biblical Authority, and Recent Proposals for Re-Doing Evangelical Theology: A Critical Analysis in Reclaiming the Center: Confronting Evangelical Accommodation in Postmodern Times, eds. Millard J. Erickson, Paul Kjoss Helseth, and Justin Taylor. - Wheaton, ILL: Crossway Books, 2004. 